\title{
KARSINOMA MEDULER TIROID DIAGNOSIS MELALUI BIOPSI ASPIRASI JARUM HALUS
}

\author{
Poppy M. Lintong \\ Maria Sambuaga
}

\author{
Bagian Patologi Anatomi Fakultas Kedokteran Universitas Sam Ratulangi Manado \\ Email: magda_plin@yahoo.com
}

\begin{abstract}
Medullary carcinoma of the thyroid is a rare thyroid cancer that is derived from parafollicular cells (C cells) of the thyroid gland. It only accounts for approximately $5 \%$ of all thyroid neoplasms. We reported a case of medullary carcinoma of the thyroid in a 44-year-old woman with tetraparesis, hypokalemia, and diarrhea. She also had two lumps in the anterior and left part of her neck. Medullary carcinoma was diagnosed by using fine needle aspiration biopsy (FNAB) of both lumps. The smears showed rich cellularity of variated cells from small and large round cells, spindles, and with plasmacitoid and hyperchromatic nuclei. These cells were dispersed and clustered. The background of the amyloid mass (amorphous material) showed as magenta masses with an MGG stain and orange masses with a Pap's stain. The amyloid material is one of the diagnostic features of medullary carcinoma of the thyroid. The diagnosis can be confirmed with the patient's blood calcitonin serum. In this case, we already performed an immunocytochemical stain of calcitonin but it was negative. Altough the calcitonin stain was negative, this medullary carcinoma of the thyroid could not be excluded because the patient still showed clinical symptoms due to hypercalcitoninemia. Some studies reported that the immunoreactive reaction of the calcitonin were more than $25 \%$ of the tumor cells.
\end{abstract}

Keywords: medullary carcinoma thyroid, amyloid, fine needle aspiration biopsy

\begin{abstract}
Abstrak: Karsinoma meduler tiroid adalah keganasan kelenjar tiroid yang berasal dari sel-sel parafolikuler (sel C) kelenjar tiroid. Tumor jenis ini jarang ditemukan, hanya sekitar $5 \%$ dari semua kanker tiroid. Kami melaporkan kasus seorang wanita berusia 44 tahun dengan gejala klinis tetraparesa, hipokalemia, diare, dan disertai adanya dua benjolan sebesar bola pingpong pada leher bagian anterior dan lateral kiri. Diagnosis karsinoma meduler tiroid ditegakkan melalui pemeriksaan biopsi aspirasi jarum halus pada kedua benjolan tersebut. Hasil pemeriksaan menunjukkan hapusan seluler terdiri dari sel-sel yang bervariasi: berbentuk bulat dengan ukuran kecil dan besar, spindel, dan plasmasitoid; inti sel tampak hiperkromatik, tersebar atau berkelompok. Latar belakang terlihat bahan amorf amiloid berwarna merah magenta pada pengecatan MGG, dan berwarna jingga pada pengecatan Papanicolaou. Bahan amiloid merupakan salah satu tanda diagnostik untuk karsinoma meduler tiroid. Untuk kepastian diagnosis dapat dikonfirmasi dengan pemeriksaan kadar kalsitonin serum. Pada kasus ini pemeriksaan imunositokimia untuk kalsitonin memberi hasil negatif, namun belum dapat menyingkirkan diagnosis karsinoma meduler tiroid. Beberapa peneliti melaporkan imunoreaktif kalsitonin untuk karsinoma meduler tiroid $25 \%$ atau lebih pada sel-sel tumor tersebut.
\end{abstract}

Kata kunci: karsinoma meduler tiroid, amiloid, biopsi aspirasi jarum halus.

Karsinoma meduler tiroid adalah neoplasma neuroendokrin yang berasal dari sel-sel parafolikuler (sel-sel C) kelenjar tiroid. ${ }^{1}$ Insidennya berkisar 5-10\% dari semua 
tumor ganas kelenjar tiroid. ${ }^{2-4}$ Seperti halnya dengan sel-sel $\mathrm{C}$ yang normal, sel-sel karsinoma meduler menyekresi kalsitonin sehingga pengukuran kadar kalsitonin berperan penting dalam menegakkan diagnosis dan follow-up pasca bedah. ${ }^{1}$

Beberapa klinisi beranggapan bahwa karsinoma meduler tiroid sangat menarik karena mempunyai predisposisi herediter dan dihubungkan dengan sindrom multiple endocrine neoplasia (MEN). ${ }^{3}$ Sekitar $25 \%$ kasus karsinoma meduler dihubungkan dengan sindrom MEN 2A, MEN 2B, atau karsinoma meduler tiroid familial. Sisanya $70-75 \%$ terjadi secara sporadis. ${ }^{1,2}$ Kasuskasus yang berhubungan dengan sindrom MEN 2A atau 2B terjadi pada usia muda dan sering pada dekade I. Berbeda halnya karsinoma meduler sporadis sering ditemukan pada usia dewasa dengan puncak insiden pada usia 40-an dan 50-an, ${ }^{1}$ dan lebih banyak pada wanita. $^{3}$ Umumnya penderita karsinoma meduler tiroid sporadis memperlihatkan massa tumor yang tidak nyeri, dengan atau tanpa limfadenopati di daerah leher. ${ }^{2}$

Karsinoma meduler yang diturunkan secara herediter umumnya didahului oleh hiperplasia sel C. ${ }^{1-4}$ Data ini menyokong pendapat yang menyatakan bahwa proliferasi sel $\mathrm{C}$ menunjukkan keganasan preinvasif (karsinoma in situ). Hiperplasia sel $\mathrm{C}$ juga terjadi pada penderita hiperkalsemia, hipergastronemia, Hashimoto's disease, dan neoplasma sel folikuler. ${ }^{2}$ Karsinoma meduler yang diturunkan secara herediter bersifat otosomal dominan dan merupakan komponen dari sindrom MEN 2A (MEN IIA atau Sipples syndrome), MEN 2B (MEN IIb, MEN III atau neuroma syndrome), atau familial non-MEN medullary thyroid cancer $(F M T C){ }^{3}$ Sindrom-sindrom ini umumnya terjadi karena mutasi proto-onkogen RET pada garis germinal. ${ }^{2,3}$ Mutasi pada protoonkogen RET mula-mula diimplikasikan pada sindrom kanker meduler familial melalui analisis mutasional. Mutasi RET pada keluarga dengan sindrom MEN-2A $(95 \%$ dari keluarga) dan FMTC (85\% dari keluarga) terlihat pada satu dari lima cysteine codons pada exon 10 dan 11. Kasus-kasus
FMTC yang menunjukkan dua mutasi tambahan mencakup codon 768 (exon 13) dan codon 804 (exon 14). Mutasi titik pada codon 918 (exon 160) sering terlihat pada 95\% kasus dengan sindrom MEN 2B. Oleh karena karsinoma meduler dianggap mempunyai mortalitas tinggi, maka direkomendasikan pada anggota keluarga dari individu yang terkena untuk melakukan skrining genetik. Bila skrining menunjukkan hasil positif, maka dianjurkan agar segera dilakukan tindakan profilaksis berupa tiroidektomi total. Hal seperti ini masih diperdebatkan namun sebagian besar ahli endokrin dan endokrin pediatrik merekomendasikan tiroidektomi total sebelum usia enam tahun bilamana ditemukan mutasi RET pada garis germinal. $^{3}$ Mutasi RET juga terlihat pada kanker meduler sporadis, biasanya pada selsel tumor dan jarang pada garis germinal. Bilamana hal ini ditemukan pada garis germinal maka kemungkinan penyakit yang familial dapat dipertimbangkan. ${ }^{3}$

Ukuran tumor karsinoma meduler bervariasi dari ukuran $<1 \mathrm{~cm}$ (mikrokarsinoma) sampai kadang-kadang dapat menggantikan seluruh lobus kelenjar tiroid. Umumnya tumor berbatas jelas tapi tidak berkapsul. ${ }^{2,3}$ Dapat ditemukan tunggal atau multipel. Biasanya pada karsinoma meduler sporadik berbentuk tunggal sedangkan karsinoma meduler familial berbentuk multipel dan bilateral. $^{1-3,5}$ Tumor ini biasanya berlokasi pada $2 / 3$ bagian atas lateral, yaitu tempat dimana konsentrasi sel $\mathrm{C}$ paling tinggi. ${ }^{3}$ Sebagian besar tumor berwarna merah muda sampai coklat, dan umumnya berkonsistensi lunak; bagian lainnya berkonsistensi keras dan fibrotik dengan daerah-daerah diskolorisasi yang menunjukkan kalsifikasi fokal. Tumor yang lebih kecil sering ditemukan pada batas $1 / 3$ bagian atas dan tengah lobus tiroid. ${ }^{2}$ Tumor berukuran besar sering mengandung daerah-daerah nekrosis dan hemoragik, dan dapat meluas melewati kapsul kelenjar tiroid. ${ }^{1}$

Karsinoma meduler bentuk familial maupun sporadis mempunyai gambaran histologik dengan spektrum luas yang dapat menyerupai semua tumor primer pada kelenjar tiroid. Biasanya karsinoma meduler 
tiroid mempunyai pola pertumbuhan lobuler, trabekuler, insular, atau dalam lembaran (sheet). Sel-sel tumor dapat berbentuk bulat, poligonal, kumparan, dan sering berupa campuran dari sel-sel ini. ${ }^{1,2}$ Mempunyai inti dengan kromatin kasar atau berbintik-bintik (tampak seperti garam dan merica) dan umumnya tidak mempunyai nukleoli. Beberapa inti dapat mengandung pseudoinklusi berupa nuclear groove seperti yang ditemukan pada karsinoma papiler sehingga dapat menyebabkan terjadinya kesalahan diagnosis. ${ }^{2,3}$ Sitoplasma bervariasi dari eosinofilik sampai basofilik. ${ }^{2}$ Karsinoma meduler dapat juga menunjukkan gambaran morfologi seperti sel-sel spindel sehingga menyerupai tumor mesenkim tiroid primer atau metastatik, karsinoma anaplastik atau tumor tiroid asal timus. Juga terdapat beberapa pola histologik lainnya seperti sel oksifil dan skuamous, sel datia, pseudopapiler, karsinoid, insular, dan campuran meduler dan papiler. Beberapa tumor terdiri dari sel-sel kecil mirip dengan small cell carcinoma pada keganasan paru. ${ }^{3}$

Amiloid dapat terlihat pada lebih $80 \%$ dari karsinoma meduler tiroid. Pengecatan Congo red dan mikroskop cahaya polarisasi dapat digunakan untuk mendiagnosis tumor ini. Kurangnya amiloid belum dapat menyingkirkan diagnosis suatu karsinoma meduler karena sekitar $25 \%$ dari karsinoma meduler ternyata kurang mengandung amiloid. Kadang kadang suatu karsinoma meduler dapat mengandung banyak amiloid sehingga sel-sel tumor sulit diidentifikasi dan dapat juga terjadi kesalahan didiagnosis sebagai amyloid goiter. ${ }^{3}$

Standar emas untuk mendiagnosis karsinoma meduler adalah pemeriksaan imunohistokima untuk kalsitonin. Pewarnaan kalsitonin dilakukan pada keduanya, yaitu sel-sel tumor dan amiloid. Karsinoma meduler dengan kalsitonin negatif sudah dilaporkan, tetapi biasanya tumor ini tergolong familial dan dihubungkan dengan hiperplasia sel-sel C. Petanda lain yang dapat digunakan untuk diagnosis ini adalah imunohistokimia untuk calcitonin gene-related peptide (CGRP). Petanda-petanda ini juga dapat digunakan pada tumor yang bukan berasal dari kelenjar seperti islet cell tumor dan smal cell carcinoma paru. Karsinoma meduler juga memperlihatkan reaksi positif untuk carcinoembryogenic antigen (CEA). Peningkatan kadar CEA serum bersamaan dengan nilai kalsitonin sering digunakan dalam follow-up penderita berisiko tinggi untuk memantau apakah terjadi rekurensi atau metastasis. ${ }^{3}$ Kalsitonin ditemukan pada 80-90\% dari tumor meduler. Meskipun beberapa kasus menunjukkan imunoreaktif untuk kalsitonin pada seluruh tumor, namun lainnya hanya menunjukkan reaktifitas yang fokal dan lemah. ${ }^{2}$

Gambaran sitologik dari karsinoma meduler cukup bervariasi. ${ }^{2,4,6,7}$ Sediaan hapus biasanya seluler, umumnya sel-sel tersebar atau berkelompok dengan ikatan kohesif yang kurang. Sel-sel bervariasi dari sel-sel kecil dan bulat, pleomorfik, kuboidal, kumparan dan plasmasitoid (inti cenderung terletak eksenstrik)., ${ }^{2,6,7}$ Kromatin inti granuler kasar, nukleoli kecil, kadang ada pseudoinklusi. ${ }^{2,6,8,9}$ Beberapa sel tersebar dengan sitoplasma bergranul kasar berwarna merah. ${ }^{4,7,9}$ Kadang-kadang terlihat sel dengan inti besar, berinti dua atau banyak, dan inklusi sitoplasmik yang serupa dengan pada karsinoma papiler. ${ }^{4}$ Latar belakang bahan amorf amiloid berwarna merah muda sampai ungu dan bereaksi positif untuk pewarnaan kalsitonin. ${ }^{2,5,7-9}$ Pada pewarnaan Papanicolaou amiloid sulit dibedakan dengan koloid, namun pewarnaan Congo red dapat dilakukan untuk konfirmasi adanya amiloid. ${ }^{2,6,8}$

Gambaran klinik dari kasus karsinoma meduler sporadis sering ditandai oleh adanya massa tumor di daerah leher, kadangkadang dihubungkan dengan efek-efek lokal seperti disfagia atau suara parau. Sedangkan pada beberapa kasus manifestasi awal berupa sindrom paraneoplastik yang disebabkan oleh sekresi hormon peptida, antara lain diare yang disebabkan oleh vasoactive intetinal polypeptide (VIP) dan Cushing syndrome yang disebabkan oleh sekresi adrenocorticotropic hormone (ACTH). Hipokalsemia bukan merupakan tanda utama meskipun kadar kalsitonin meningkat. Dalam hal ini sekresi CEA oleh sel-sel neo- 
plastik merupakan penanda yang sangat berguna untuk penilaian tumor pra bedah dan tumor-tumor dengan kalsitonin negatif. ${ }^{1}$ Penderita karsinoma meduler sporadis menunjukkan tanda-tanda dan gejala yang dihubungkan dengan prroduksi hormon kalsitonin, peptida, amin, atau prostaglandin. Penderita dengan metastasis dapat menunjukkan diare berat atau flushing; gejalagejala ini dihubungkan dengan kadar kalsitonin darah yang tinggi. ${ }^{2}$ Sel-sel karsinoma meduler juga mengekspresikan bcl2 dan c-myc, tetapi bukan Bax atau p53. ${ }^{10}$ Gambaran klinik karsinoma meduler familial dapat berbeda-beda. Karsinoma meduler pada MEN 2A dihubungkan dengan hiperplasia sel C, feokromositoma adrenal, hiperplasia meduler adrenal, dan hiperplasia paratiroid; hal ini dapat ditemukan pada 16$25 \%$ kasus. Karsinoma meduler pada MEN 2B ditandai dengan gambaran klinik yang lebih agresif dan kematian dapat terjadi pada usia dini yang diakibatkan oleh metastasis jauh. ${ }^{1,3,10}$ Komponen lain dari sindrom ini meliputi hiperplasia sel $\mathrm{C}$, feokromositoma, hiperplasia meduler adrenal, neuroma mukosa, ganglioneuroma gastrointestinal, dan gangguan muskuloskeletal. ${ }^{3}$

Karsinoma meduler dapat mengadakan invasi lokal dan sering bermetastasis ke kelenjar getah bening di daerah leher dan mediastinum, serta juga pada organ jauh seperti paru-paru, hati dan tulang. Hal ini lebih sering terjadi pada karsinoma meduler sporadis dan sindrom MEN 2B. ${ }^{10}$

Faktor-faktor prognostik karsinoma meduler mencakup hal-hal sebagai berikut: tumor sporadis atau meduler, usia penderita, ukuran tumor dan stadium klinisnya. Juga terdapat faktor-faktor patologik yang mencakup jumlah amiloid, pleomorfisme inti, nekrosis, sitologik sel kecil, metastasis ke kelenjar getah bening, invasi ke pembuluh darah, penyebaran keluar dari kelenjar tiroid, serta status DNA aneuploid pada pengukuran flow cytometry. Beberapa ahli melaporkan bahwa imunoreaktif untuk kalsitonin $25 \%$ atau sel-sel tumor yang lebih sedikit dan ditandai oleh CEA positif menunjukkan prognosis lebih baik, namun belum terdapat kesepakatan bersama. ${ }^{3}$

\section{LAPORAN KASUS}

Seorang wanita berusia 44 tahun dirawat di Bagian Ilmu Penyakit Dalam RSU Prof. Dr. R. D. Kandou dengan diagnosis kerja tetraparesis dan paralisis periodik et causa hipokalemia berat; juga disertai gejala gastroenteritis akut (diare) serta aritmia. Terdapat benjolan sebesar bola pingpong berdiameter $4-5 \mathrm{~cm}$ pada leher bagian anterior dan lateral kiri yang dialami sejak sembilan bulan sebelum masuk rumah sakit. Pada pemeriksaan laboratorium didapatkan hemoglobin $12,2 \mathrm{~g} / \mathrm{dl}$, hematokrit $31,9 \%$, lekosit $12.400 / \mathrm{mm}^{3}$, dan trombosit $496.000 / \mathrm{mm}^{3}$, Gula darah sewaktu 144/mg/dl, ureum 35,2 $\mathrm{mg} / \mathrm{dl}$, kreatinin $1 \mathrm{mg} / \mathrm{dl}$, natrium 123 $\mathrm{mmol} / \mathrm{L}$, kalium $\downarrow \downarrow \downarrow$ mmol/L, dan klorida $92 \mathrm{mmol} / \mathrm{L}$. Riwayat penyakit dahulu: pada usia 27 tahun pernah dilakukan operasi pada kelenjar tiroid, dengan hasil pemeriksaan histopatologi adenoma tiroid. Riwayat penyakit dalam keluarga: hanya penderita yang sakit seperti ini. Penderita kemudian di konsul ke bagian Patologi Anatomi Fakultas Kedokteran Universitas Sam Ratulangi untuk dilakukan pemeriksaan biopsi aspirasi jarum halus pada benjolan di daerah lehernya. Hasil pemeriksaan biopsi aspirasi jarum halus tersebut menunjukkan hapusan seluler terdiri dari sel-sel yang bervariasi dari berbentuk bulat ukuran kecil dan besar (Gambar 1), plasmasitoid (Gambar 2), dan kumparan (Gambar 3). Terdapat juga sel-sel dengan inti hiperkromatik yang tersebar dan berkelompok. Latar belakang terlihat bahan amorf amiloid berwarna merah magenta dengan pengecatan MGG dan jingga dengan Papanicolau (Gambar 4). Dari bahan aspirat dibuat hapusan lagi kemudian dikirim ke Departemen Patologi Anatomi Fakultas Kedokteran Universitas Indonesia (FKUI) Jakarta untuk dilakukan pemeriksaan imunositokimia, namun hasilnya tidak ditemukan sel penanda tiroid dan tidak ditemukan sel $\mathrm{C}$ atau kalsitonin negatif. 

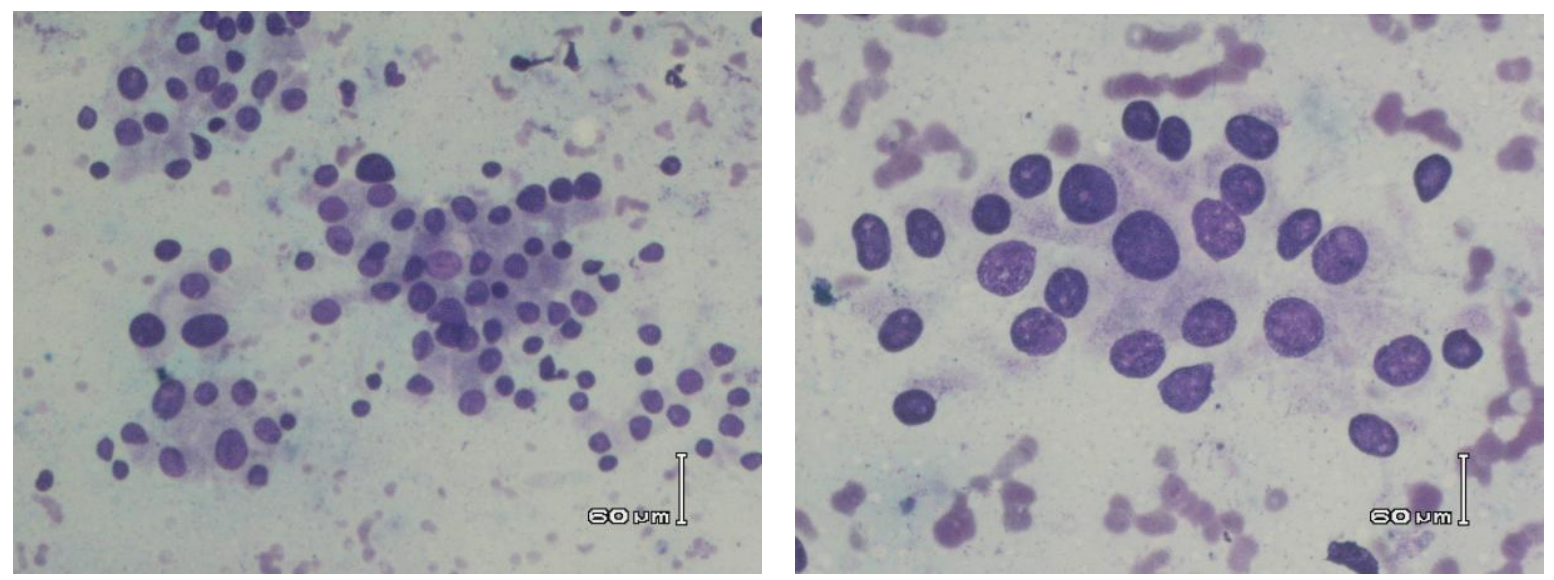

Gambar 1. Gambaran mikroskopik dari hasil pemeriksaan biopsi aspirasi jarum halus benjolan di daerah leher menunjukkan gambaran sel yang bervariasi ukurannya dari kecil sampai besar.
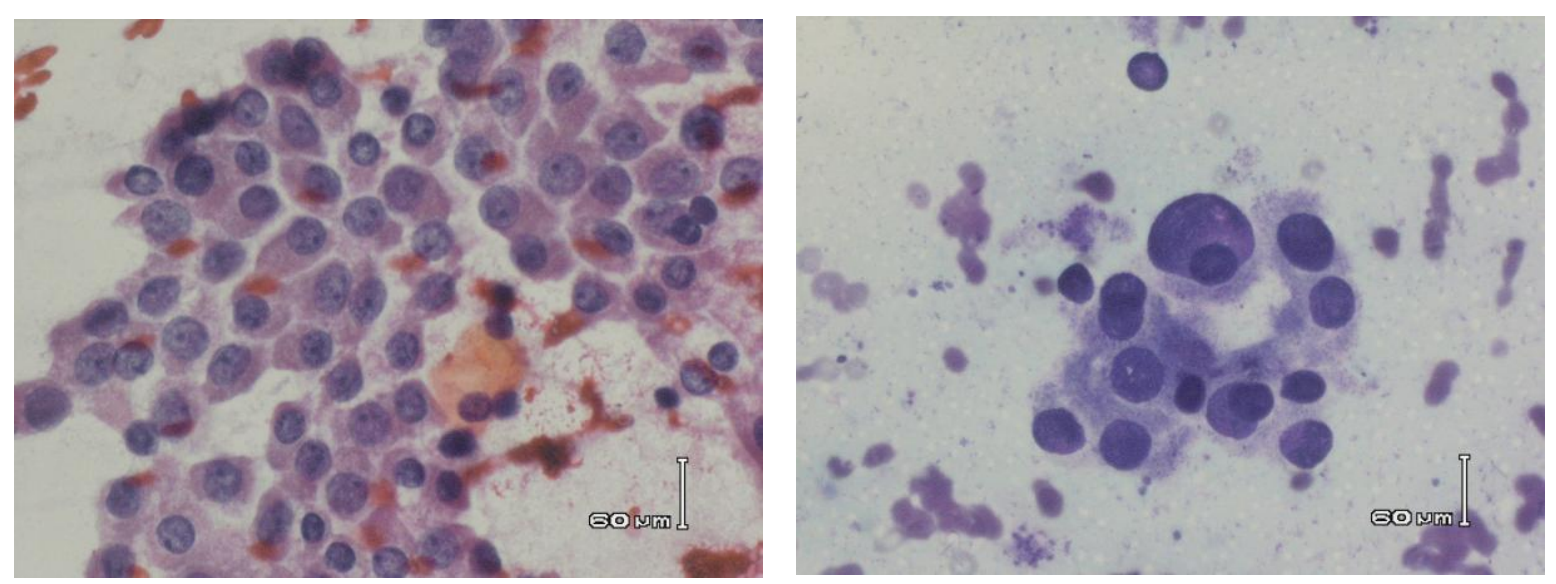

Gambar 2. Gambaran mikroskopik dari hasil pemeriksaan biopsi aspirasi jarum halus benjolan di leher menunjukkan gambaran sel plasmasitoid (seperti sel plasma dengan inti terletak eksentrik).
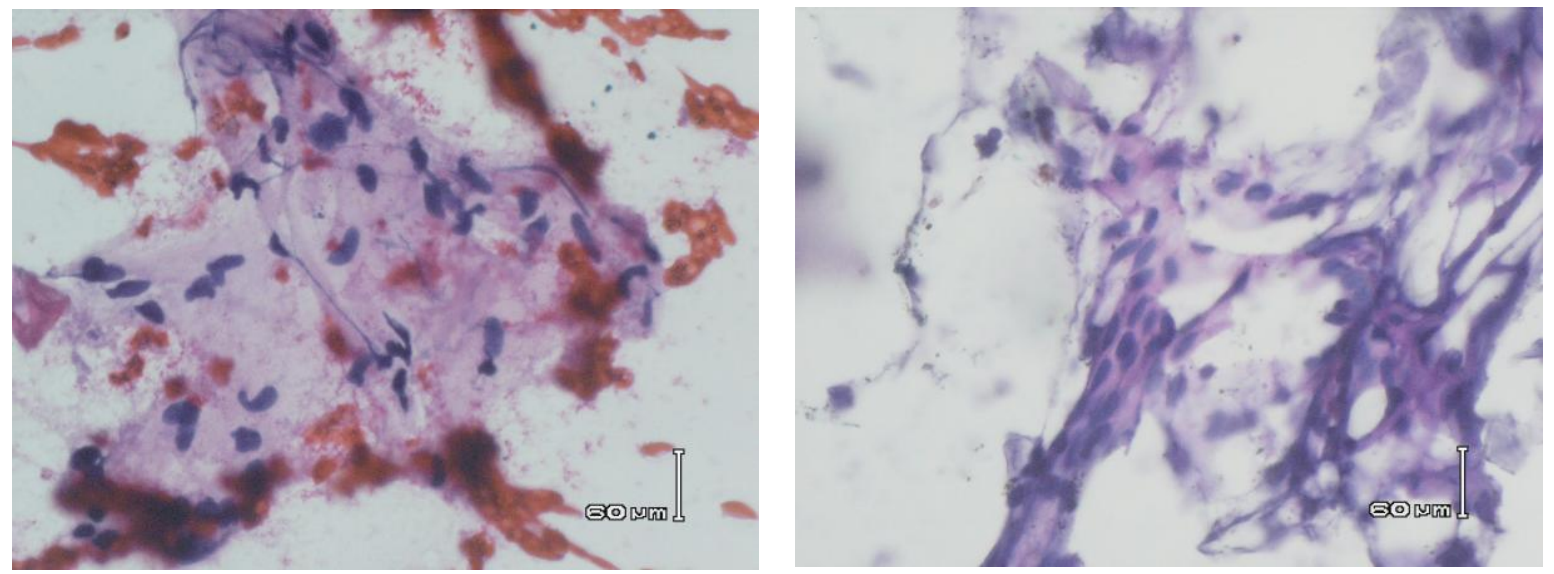

Gambar 3. Gambaran mikroskopik dari hasil pemeriksaan biopsi aspirasi jarum halus benjolan di leher menunjukkan sel-sel yang berbentuk kumparan 

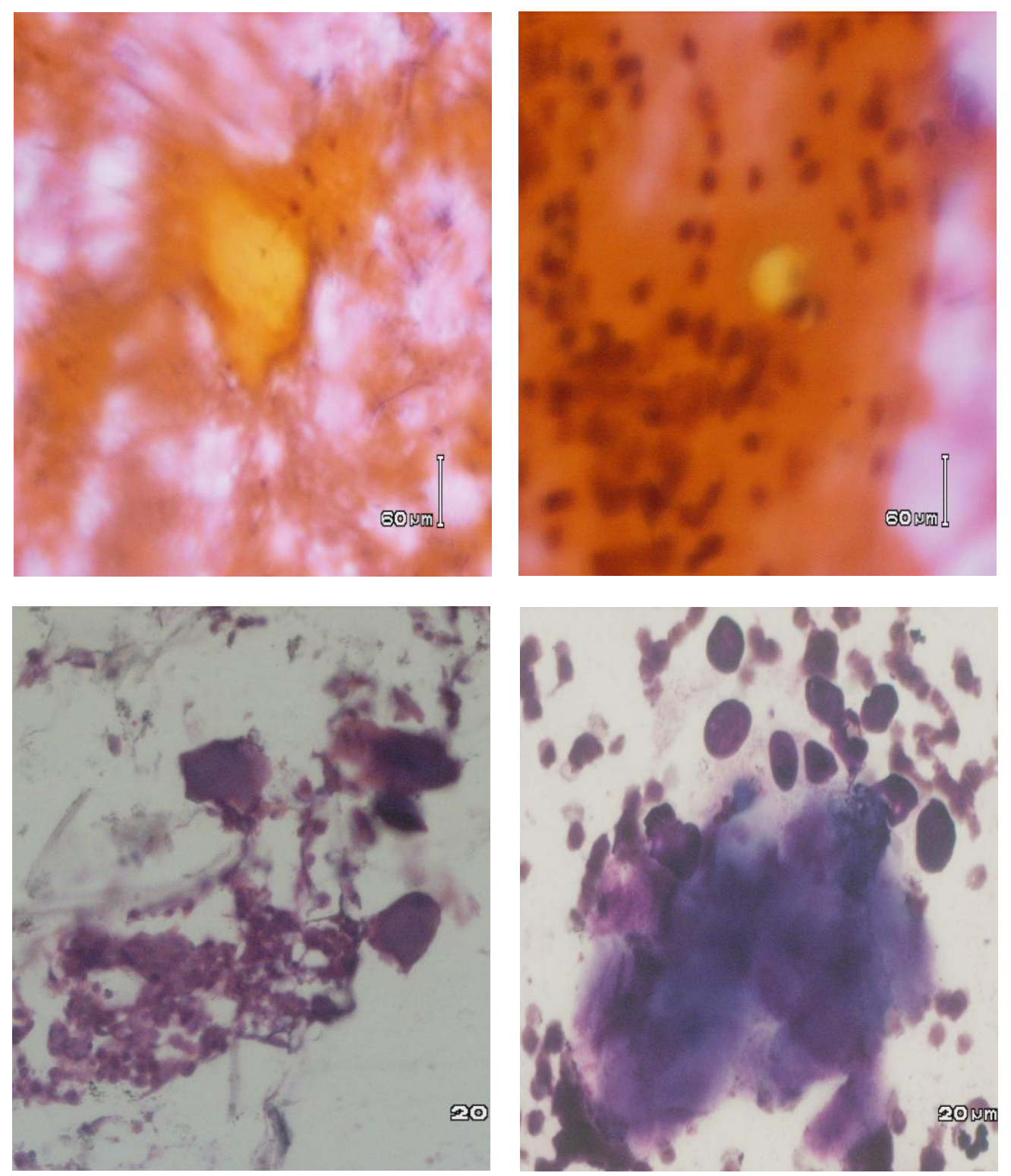

Gambar 4. Gambaran mikroskopik dari hasil pemeriksaan biopsi aspirasi jarum halus benjolan di daerah leher menunjukkan bahan amorf (amiloid) berwarna jingga dengan pengecatan Papapanicolau (atas), dan merah magenta dengan pengecatan MGG (bawah)

\section{BAHASAN}

Karsinoma meduler tiroid sporadik sering ditemukan pada usia diatas 40 tahun. Jenis ini ditandai oleh pertumbuhan progresif perlahan dengan metastasis awal pada kelenjar getah bening daerah leher, hati dan tulang. ${ }^{4}$ Kasus ini seorang penderita berusia 44 tahun. Dipandang dari segi usia dan jenis kelamin penderita (wanita), maka kasus ini digolongkan sebagai karsinoma meduler tiroid sporadis disertai metastasis awal pada kelenjar getah bening leher. ${ }^{3}$ Berdasarkan riwayat penyakit yang dialami, saat berusia
27 tahun (17 tahun yang lalu) penderita pernah dilakukan operasi tumor kelenjar tiroid lobus kanan dengan hasil diagnosis histopatologi adenoma folikuler tiroid. Diperkirakan adenoma folikuler yang dialami 17 tahun lalu tidak berhubungan dengan penyakit yang dialami sekarang karena terjadinya karsinoma meduler tiroid baik sporadis maupun herediter berhubungan dengan mutasi pada protoonkogen $\mathrm{RET}^{3}$, sedangkan adenoma folikuler berasal dari sel-sel epitel folikel tiroid dan umumnya disebabkan oleh mutasi somatik pada reseptor TSH. ${ }^{1}$ 
Pada kasus ini diagnosis karsinoma meduler ditegakkan melalui pemeriksaan biopsi aspirasi jarum halus. Gambaran sitologik yang didapat dari sediaan hapus sesuai dengan karsinoma meduler tiroid yaitu sel-sel bervariasi dengan ukuran kecil dan besar (Gambar 1), bentuk plasmasitoid (Gambar 2), kadang berbentuk kumparan (Gambar 3); dan terdapatnya bahan amiloid berbentuk bahan amorf berwarna kuning jingga dengan pengecatan Papanicolaou dan berwarna merah magenta dengan pengecatan MGG (Gambar 4). Dari bahan biopsi aspirasi jarum halus dibuat hapusan juga untuk pemeriksaan immunostaining atau imunositokimia untuk kalsitonin di Bagian Patologi Anatomi FKUI namun hasilnya negatif. Walaupun demikian, hasil negatif pada kasus ini belum dapat menyingkirkan diagnosis karsinoma meduler tiroid sebab terdapat kasus yang memperlihatkan imunoreaktif kalsitonin pada seluruh tumor, sedangkan yang lainnya hanya menunjukkan reaktifitas yang fokal dan lemah. ${ }^{2}$ Hasil studi yang dilakukan pada 38 kasus karsinoma meduler tiroid yang didiagnosis berdasarkan gambaran sitomorfologik dari bahan biopsi aspirasi jarum halus dengan pemeriksaan imunositokimia memperlihatkan $74 \%$ kasus positif untuk kalsitonin. ${ }^{13}$ Pemeriksaan imunohistokimia untuk kalsitonin merupakan standar emas untuk mendiagnosis karsinoma meduler yang ditujukan pada sel-sel tumor dan amiloid. ${ }^{3}$ Diagnosis karsinoma meduler tiroid melalui pengukuran kalsitonin pada bahan biopsi aspirasi jarum halus telah banyak dilakukan. Ditegaskan bahwa pengukuran kadar kalsitonin melalui jarum pada pemeriksaan biopsi aspirasi jarum halus tumor karsinoma meduler tiroid merupakan suatu pendekatan baru untuk mendiagnosis karsinoma meduler tiroid. ${ }^{11}$ Oleh karena dengan pemeriksaan biopsi aspirasi jarum halus pada kanker tiroid kadang sulit dibedakan antara jenis papiler dan meduler, maka petanda kalsitonin dengan pewarnaan imunositokimia sangat bermanfaat untuk menentukan suatu karsinoma meduler tiroid. $^{12}$

Gejala klinik pada penderita ini adalah diare yang disertai dengan hipokalemia se- hingga penderita mengalami paralisis dan aritmia pada saat masuk rumah sakit. Hal ini mencerminkan adanya sindrom karsinoid dan sindrom paraneoplastik dimana terjadi sekresi hormon peptida yang mengakibatkan diare. ${ }^{1}$ Selain itu, juga disebutkan bahwa hiperkalsitoninemia dapat menimbulkan gejala-gejala pada saluran cerna seperti diare. $^{3}$

\section{SIMPULAN}

Telah dilaporkan kasus karsinoma meduler tiroid pada seorang wanita berusia 44 tahun yang terjadi sporadis, dengan gejala klinik diare, hipokalemia, paralisis, dan aritmia.

Diagnosis karsinoma meduler tiroid ditegakkan melalui pemeriksaan biopsi aspirasi jarum halus pada kedua tumor di daerah leher. Pemeriksaan immunostaining untuk kalsitonin melalui bahan biopsi aspirasi jarum halus merupakan pendekatan baru untuk mendiagnosis karsinoma meduler tiroid.

Walaupun pada kasus ini pemeriksaan imunositokimia memberi hasil negatif , hal ini belum dapat menyingkirkan diagnosis karsinoma meduler tiroid karena gambaran sitologiknya yang sangat menunjang dan adanya gejala klinik diare yang dapat mencerminkan adanya hiperkalsitoninemia.

\section{DAFTAR PUSTAKA}

1. Anirban M. The endocrine system. In: Kumar V, Abbas A, Fausto N, Aster JC, editors. Robbins and Cotran Pathologic basis of disease (Eight Edition). Philadelphia: Elsevier Saunders, 2010; p. 1118-26.

2. DeLellis RA. Tumors of the thyroid gland (C-cells). In: Khan A, Giordano A, editors. Surgical pathology of endocrine and neuroendocrine tumors. New York: Human Press, 2009; p. 83-94.

3. Baloch ZW, Livolsi VA. The thyroid gland. In: Silverberg SG, DeLellis RA, Frable WJ, Livolsi VA, Wick MR, editors. Silverberg's principles and practice of surgical pathology and cytopathology Vol.2 (Fourth Edition). Philadelphia: Churchill Livingstone Elsevier, 2006; p. 2135-9. 
4. Davidson GH, Campora GR. Thyroid. In: Bibbo M, Wilbur DC, editors. Comprehensive cytopatholgy (Third Edition) Saunders Elsevier, 2008; p. 654-5.

5. Sanchez MA, Stahl RE. The thyroid, parathyroid, and neck mass other than lymph nodes. In: Koss LG. Koss' Diagnostic cytology and its histopathologic bases Fifth Edition). Lippincott Williams and Wilkins, 2006; p. 1167-9.

6. Logani S, Balach ZW. Fine needle aspiration cytology of endocrine tumors. In: Khan A, Giordano A, editors. Surgical pathology of endocrine and neuroendocrine tumors. New York: Human Press, 2009; p. 12-82.

7. Orell SR, Sterrett GF, Max NI, Whitaker DW, Gladwyn L. Manual and atlas of fine needle aspiration cytology (Fourth Edition). London: Elsevier, 2005; p. 151-4.

8. Ramzy I. Thyroid and parathyroid glands. In: Clinical cytopathology and aspiration biopsy fundamental principles and practice (Second Edition). Hongkong:
Mc.Graw-Hill, 2001; p. 376-8.

9. Cibas ES. Thyroid. In: Cibas ES, Ducatman BS, editors. Cytology diagnostic principles and clinical correlates (Third Edition). Philadelphia: Saunders Elsevier, 2009; p. 277-79.

10. Rosai J. Rosai and Ackerman's Surgical pathology (Ninth Edition) Vol.1. London: Mosby, 2004; p. 555-9.

11. Kudo T, Miyauchi A, Ito Y, Takamura Y, Amino N, Hirokawa M. Diagnosis of medullary thyroid carcinoma by calcitonin measurement in fine-needle aspiration biopsy specimens. Thyroid 2007;17(7):635-8.

12. Kono T, Yamazaki K. Aspiration cytologic features of thyroid medullary carcinoma. Journal of the Japanese Society of Clinical Cytology, 2007;4(1):1-6.

13. Shika B, Kusum K, Kusum V. Medullary carcinoma of the thyroid: A cytological, immunocytochemical, and ultrastructural study. Diagnostic cytopathology [serial online]. 2006 [cited 2010 Aug 10]; 8: 2832. Available from: URL: www. Wiley.com. 